\title{
Investigating The Extent That An Integrative Learning Module Broadens The Perception Of First-Year Students About The Engineering Profession
}

\author{
Kerri Patrick Singer, University of Georgia, USA \\ Tim Foutz, University of Georgia, USA \\ Maria Navarro, University of Georgia, USA \\ Sidney Thompson, University of Georgia, USA
}

\begin{abstract}
Engineers today need both engineering knowledge and social science knowledge to solve complex problems. However, most people have a traditional view of engineering as a field dominated by math and science foci, with little social consequence. This study examined and compared perceptions about engineering from Freshmen taking three different First Year introductory courses. Researchers used data from students' responses in the Draw-an-Engineer-Test, an engineering problem analysis assessment, and interviews. The Treatment Group were students in an introductory engineering course in which they received instruction using an integrative learning module entitled, the "Water Module", based on interdisciplinary learning theory. Control Group 1 were students in a "Traditional Engineering" course, and Control Group 2 were students taking a "Non-Engineering" course. Results indicate that students in the Treatment Group developed a better understanding of engineering and its social impact on society versus the two Control Groups. We suggest that integrative and interdisciplinary learning modules are effective for broadening students' perspectives on engineering and its role in society.
\end{abstract}

Keywords: Interdisciplinary Education; Draw-An-Engineer-Test; Integrative Learning; Recruiting And Retaining Engineering Students

\section{INTRODUCTION}

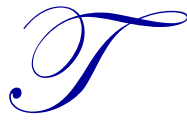

he selection of a college major by a high school student is greatly influenced by her/his prior knowledge of the characteristics of the careers associated with that major (Beggs, Bantham, \& Taylor, 2008; Walmsely, Wilson, \& Morgan, 2010). This has tremendous implications for engineering programs because students, as well as the general public, typically have limited views of the engineering profession. Studies have shown that middle school and high school students have a narrow perspective of what engineers do, limited for example to mechanics, maintenance workers, and construction workers (English, Hudson, Dawes, 2011; Bowen, Prior, Lloyd, Thomas, \& Newman-Ford, 2007; Knight \& Cunningham, 2004), and are not aware of the contributions that engineers can make to solve global challenges and the impact they can have in society. When students are exposed to advanced engineering topics and application coursework, their understanding of the widerange of careers that engineers expands, and their interest in an engineering profession increases (Fantz, Siller, \& DeMiranda, 2011; Oware, Capobianco, \& Diefes-Dux, 2007). It is important that students be exposed to engineering applications early enough in school to have an impact on engineering enrollment and retention. The engineering design process has been shown to impact positively middle school and high school students' understanding of the mathematical and natural sciences (Foutz, Navarro, Hill, Thompson, Miller \& Riddleberger, 2011). 
In addition to the difficulty of attracting high school students directly to engineering majors, engineering programs also have difficulty attracting college students who are exploring new opportunities, or trying to change majors; one study indicates that only $7 \%$ of students who graduated with an engineering degree migrated into engineering from another degree program (Ohland et al., 2008). While there is a popular belief that the lack of students transferring into an engineering major is due to concerns about academic ability and grade anxiety, a multiinstitution study found that variables such as academic qualifications, student stress over grades and engagement in extra-curricular activities are the same for engineering majors as those for students in other disciplines (Lichtenstein, McCormick, Sheppard, \& Puma, 2010). Studies (Marra, Rodgers, Shen, \& Bogue, 2012; Dabbagh \& Menascé, 2006; Walden \& Foor, 2008) indicate the failure to make the connection between curricular content and professional practice is a key factor for not attracting college students as well as high school students into an engineering major.

Connecting engineering curricular content to professional practice, however, will not be the sole factor to help attract a larger number of students into engineering degree programs. Studies indicate that many students wish to enroll in degree programs that call for social responsibility, and where they feel they will be prepared to make a difference in a global society (Clark \& Andrews, 2011; Hartman \& Hartman, 2006). Providing college freshmen with meaningful experiences that demonstrate the usefulness and societal impact of engineering work is another key factor for attracting students into engineering majors (Jones, Paretti, Hein, \& Knott, 2010). Therefore, establishing engineering-focused courses that allow first-year students to realize the role engineering has in solving societal problems, and making these courses available to all majors, could significantly improve student migration into engineering (Ettouney, 1994; Besterfield-Sacre, Atman, \& Shuman, 1998).

The University of Georgia requires all incoming freshmen to enroll in the course FYOS 1001, First-Year Odyssey Seminar, a course designed to engage students in a focused area of scholarship, develop working relationships with a faculty member, and to engage the student in the academic community. Each academic year, $350+$ sections of this course, with about 15 students each, are taught by tenure-track faculty who represent all colleges in the university. The content of the course is focused on the teaching faculty member's discipline or area of expertise and thus, all sections are different, and the content of each section is unique. Therefore, FYOS 1001 offers an opportunity to have an engineering-focused course available as a possible choice to all incoming freshmen, regardless of their declared major, allowing for "safe" exploration of unfamiliar topics. The study herein investigates the impact that a course that integrates knowledge domains of engineering, the humanities, social sciences, economics, and science has on first semester, first year students' perception of the engineering profession.

\section{PURPOSE AND OBJECTIVE}

The purpose of this study was to examine the potential of broadening the perception of first-year students about the engineering profession. The research question was "To what extent does an integrative learning module impact students' perceptions about the engineering profession?" Changes in the evolution of these perceptions were examined by comparing pre and post data from the Draw-an-Engineer-Test of students taking a course with an integrative learning module versus students taking two courses without integrative learning modules and by interpreting students' comments made during interviews.

\section{METHODS}

\section{Integrative Learning Module}

Integrative learning is an instructional design that helps students a) make connections between curricular content and career expectations, b) understand the need to have breadth and depth of knowledge from diverse disciplines, and c) engage a holistic approach to solve complex problems (Froyd \& Ohland, 2005; Wingert et al., 2011). The integrative learning module, the "Water Module," used in this study was based on issues associated with gray water irrigation as a residential water conservation practice (Singer, Foutz, Navarro, \& Thompson, 2011; Foutz, Navarro, Patrick Singer, \& Thompson, 2015). The module required students to explore controversial social issues and evaluate how these issues can influence the success of an engineered solution. The module was broken down into different components and learning tasks throughout the semester and required students to collect data and perform a thorough analysis on the issue of gray water. Using integrative activities of standard engineering calculations and humanities-based sources of data, students determined the constraints of a complex problem by 
evaluating the information compiled by studying historical events, interviewing affected citizens, and scrutinizing the information provided by government agencies and water management experts. This process required students to engage in research of government documents and evaluate their creditability, as well as interview stakeholders who are not engineering experts on their concerns or views on gray water use. The students learned that they cannot merely make engineering decisions without consulting a broad range of constituents. Students were divided into groups, and each group collected and analzyed their data for each of the components of the class. At the end of the semester, students were required to draw their own conclusions on the feasibility of gray water use and present their arguments to the class. Thus, the module was meant to invoke a more holistic analysis of engineering problems by demonstrating how social issues impact engineering decisions (Singer, Foutz, Navarro, \& Thompson, 2011; Foutz, Navarro, Patrick Singer, \& Thompson, 2015).

\section{Research Groups}

The procedures used in this study were approved by the Institutional Review Board (IRB), the University of Georgia research oversight committee responsible for ensuring human subject research is conducted in compliance with the applicable federal, state and institutional policies and procedures. This study was assigned the IRB study number 2012100931. While all students completed all assessment instruments, only the responses from students who consented to take part in the research portion of the assessment are included in this study.

Students in three sections of FYOS 1001 were used as research groups, "Traditional Engineering," "NonEngineering" and "Water Module." Students in the "Traditional Engineering" group were enrolled in the FYOS 1001 course section entitled, World Trade Center: From Beginning to End. Course content focused on the fundamental principles of structural design, safety features, and failure of the World Trade Center Twin Towers. This section was taught by a civil engineering faculty member whose expertise included storage structures and who primarily taught structural engineering courses. This course section had 13 first semester, first-year students; two of these students were engineering majors.

Students in the "Non-Engineering" group enrolled in an FYOS 1001 course section entitled, Poverty in the Movies. Course content focused on the causes, effects, and solutions to local and global poverty, and used movies that depict poverty in different parts of the world as case studies to generate discussion and help students analyze poverty and the representation of poverty. The instructor was an agricultural education faculty member who conducted research in agricultural and international education. This professor was not in an engineering department but has a degree in engineering. Thirteen students were enrolled in this course section, and none of these students were engineering majors. This group was used as a control to see in students not studying an engineering course had any greater or lesser understanding of engineering work and humanities connections to engineering than those who registered for an engineering course.

Students in the "Water Module" treatment group enrolled in the FYOS 1001 course section entitled, Engineering and a Liberal Education. Course content focused on the historical, social and technical issues associated with water conservation restrictions that the local government implemented as a response to the 2006-2009 extreme drought experienced by the citizens of Athens, Georgia. The course was taught by a faculty member who had expertise in engineering biomechanics and who taught freshmen level courses in systems engineering and upperlevel courses on design methodology. Eleven students were enrolled in this section; two students were engineering majors, and another student who majored in business had a strong interest in industrial engineering.

\section{DATA COLLECTION \& ANALYSIS}

\section{Draw-an-Engineer Test}

This test was an adaptation from the study by (Knight \& Cunningham, 2004), which was originally based on the Draw-A-Scientist Test (DAST) (Chambers, 1983). The DAST has been successfully used to examine students' stereotypes, general knowledge, and perceptions about engineers or scientists, and as a tool to evaluate the effectiveness of curriculum and experiences focused on expanding students perspectives about science (Miele, 2014; Milford \& Tippett, 2013). In this study, it was used to investigate students' perceptions of engineers and 
engineering's interaction with social issues. Specifically, students were asked to draw a schematic of what they thought the word "engineer" means and were also given the opportunity to elaborate on the meaning of the picture in writing. Therefore, the interpretation of the students' perceptions of engineers was not solely based on the drawing. Students completed their first drawing at the beginning of the semester before the integrative learning module was used with the "Water Module" group (pre-test), and completed their second drawings at the end of the semester (post-test). Students were not given their first drawing when asked to prepare the second one. A Ph.D. candidate who was majoring in Social Foundations of Education, and who was not associated with teaching the courses, interpreted and analyzed the images and the accompanying text. Differences between the first and second drawings were noted and counted for four major themes: image, engineering process, humanities and social science integration, and types of knowledge. The overall question was whether or not students understood engineering generally and if they understood the integrated aspects of engineering with social elements. The images were analyzed for their use of detail and explanations that would indicate a working knowledge of an engineer's daily work. Images were analyzed and coded for emerging themes by the Ph.D. candidate and then reviewed by other members of the research team to determine any additional codes that were missed. When the second drawings were completed, the first drawings were analyzed again to determine if any potential meanings were missed in the prior analysis. Comparison charts of each pair of drawings were composed by the Ph.D. candidate and reviewed by the research team. The Ph.D. candidate also obtained additional assessment from peers working in engineering as additional reviewers to gather any analytical points that may have been missed. The iterative review by several researchers was important for triangulation, a key component of trustworthiness in qualitative research (Lincoln and Guba, 1985). The major themes that resulted and that aligned with the study focus are described below.

Image

Drawings were analyzed based on the appearance of the engineering figure, such as clothing, personality, gender, tools, materials, place of work, blue collar or white collar style, surrounding. Image answered the question of "who" is an engineer. For example, if the first image represented stereotypes of engineers, such as males, glasses, and/or uniforms, but the second images presented a broader view of engineers with no specified gender or stereotypical traits, this was considered a change.

\section{Engineering Process}

This concept addressed any description or illustration relevant to engineering processes that include aspects of research, collaboration or teamwork, design, planning, supervision, implementation, etc. Also, any demonstration of engineering as a nonlinear process was also considered. This theme answered the question of "how" does an engineer do his/her work.

Humanities And Social Science (HSS) Integration

Any schematic depictions or words that related to any form of humanities and social science (HSS) integration were considered. Such depictions include interactions with people, societal focus, such as helping people, environmental/local context/culture concerns, and any humanitarian perceptions of engineers. This theme answered "what or who" is impacted by an engineer.

\section{Types of Knowledge}

Different emphasis on academic subjects and disciplines that are considered essential to engineering were examined. This theme answered the question of "what knowledge" is essential for an engineer. For example, if a student had drawn math and science books in the first drawing but included other subjects in the second drawing or omitted math and science in the second drawing this would have been considered a change, suggesting that the student now sees math and science are not the only valuable subjects in engineering work. If the second drawing indicated that more than math and science was needed in engineering, this also would have been considered a change. 
There was an expectation that students exposed to the integrative learning module would produce drawings that illustrated an improved understanding of engineering's interaction with social issues. The "Traditional Engineering" and the "Non-engineering" study groups were included to assess if the changes seen for the "Water Module" group were unique to that group.

Interviews

A Ph.D. candidate in Social Foundations of Education interviewed students in the "Water Module" and the "Traditional Engineering" groups. The interview included questions about perceptions of engineering and its role in society, teaching methods, and, in the case of students in the Treatment group, questions about the integrative module. Student responses were analyzed according to the following themes: perceptions of engineering, humanities and social science connections to engineering, and evaluation of teaching style.

\section{RESULTS AND DISCUSSION}

\section{Draw-An-Engineer-Test}

The drawing test was open-ended, and most students chose to draw examples or generalized depictions of engineers. Many students "evolved" in their perspectives about engineers and added different layers to their drawings. For example, one student initially depicted engineering as a linear process at the beginning of the semester (Figure 1). At the end of the semester, this same student illustrated a cyclical process that involves research, as well as consideration of social issues. Eight students in both the "Water Module" and "Traditional Engineering" groups participated in both Draw-an-Engineer tests and agreed to have their data used for this research study. Their results are summarized in Tables 1 and 2, respectively. Seven students in the "Non-engineering" group completed both Draw-an-Engineer tests (Table 3) and agreed to have their data used for this research study. Other students in the class were absent in either of the two days when the test was administered, or chose not to complete and sign the consent form for the research study.

The "Water Module" group was the only set of students who showed a change in all four themes (Table 1). Five of the eight students in this group changed their perception of the Image of an engineer shifting away from a "skilled" technical worker depiction toward a professional and business oriented person. Four students changed their perception of the Engineering Process, moving from situations where engineers unilaterally create a device to solve a problem, to one where the engineers use iterative processes to understand all aspects of a problem. Regarding the Humanities and Social Science Integration theme, six students honed their end-of-the-semester drawings to depictions of engineers who were more engaged with social issues. Only one of these students did not change her/his perception of the Types of Knowledge an engineer needed.

In the "Traditional Engineering" group, minimal changes were noted for three of the eight students in their perception of the Types of Knowledge an engineer needs (Table 2). These students indicated that engineers need to be knowledgeable of planning and designing and that the engineering process utilizes calculations to make decisions. The drawings also indicate that these students depict engineers as structural engineers and construction workers. These results are not surprising since the course was about the construction and structural design of the World Trade Center buildings. Only one student indicated a change in the Engineering Process theme and that student depicted the engineering process as linear in both drawings. The difference suggested that the students' view of the engineering process used calculations to find the "best" solution for a problem. This result is not surprising since the lectures and assignments focused on safety concerns of the Twin Towers and the structural failure of the Towers due to the terrorist attacks. However, it is surprising that only one student in this group indicated a change in this theme. The course materials presented to this group of students did not appear to influence their Image of an engineer nor the students' perception of the need to integrate engineering with the humanities and social science aspects of a problem.

Minor changes were seen in the drawings of the students in the "Non-engineering" group (Table 3). Only two students made a change in their depiction of an engineer and three students provided some level of indication that engineers had a connection with the humanities and social sciences. For example, Student J's first depiction of 
an engineer was one of an older male professional with lots of experience whereas at the end of the semester this student drew a female-like engineer who could 'look like anyone." Student L's depiction changed from a person who does manual labor to one who teaches people how to solve a problem. Students J, K and L perception of the Humanities and Social Science Integration theme changed slightly after completing the course where their depictions suggested more social connections to solving problems. Again these findings were not surprising when considering the course content focused on of the general causes, effects, and solutions to local and global poverty.

Figure 1. An example of a "Draw-an-engineer" test from a student participating in the study. This drawing indicates that the student's perspective of the engineering process changed from a linear to a cyclical process.

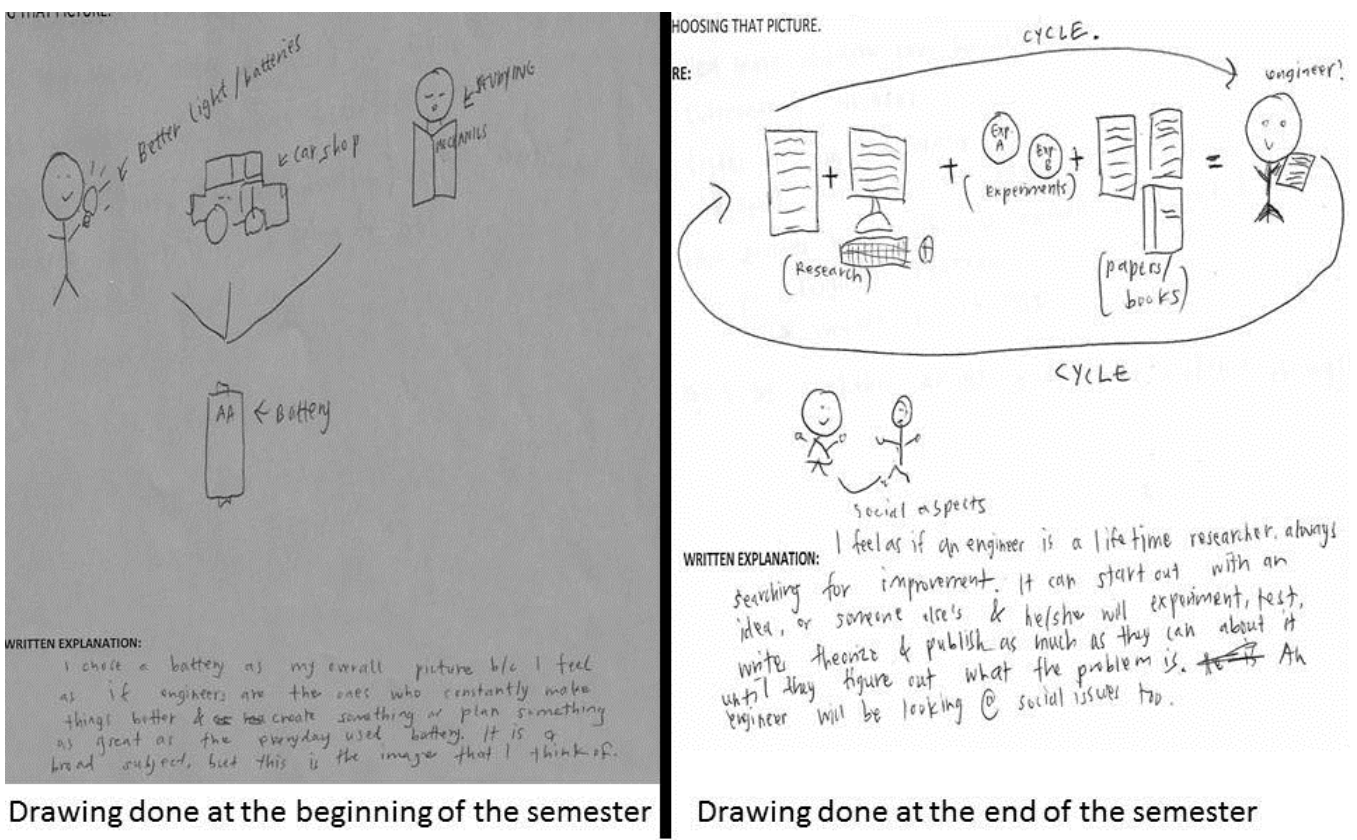


Table 1. Summary of the Comparison of the Pre and Post Draw-an-Engineer-Test from Students in the "Water Module" Treatment group

\begin{tabular}{|c|c|c|c|c|c|}
\hline & & \multicolumn{4}{|c|}{ Themes } \\
\hline Student & $\begin{array}{l}\text { Short description of the } \\
\text { changes noted in the drawing }\end{array}$ & Image & $\begin{array}{l}\text { Engineering } \\
\text { Process }\end{array}$ & $\begin{array}{l}\text { Humanities } \\
\text { and Social } \\
\text { Science } \\
\text { Aspects } \\
\end{array}$ & $\begin{array}{c}\text { Types of } \\
\text { Knowledge }\end{array}$ \\
\hline A & $\begin{array}{l}\text { Both drawings used a lot of symbolism. } \\
\text { Written explanation in the second drawing } \\
\text { indicates more types of knowledge, more } \\
\text { social issues, and more professional skills. }\end{array}$ & $*$ & + & + & $*$ \\
\hline B & $\begin{array}{l}\text { The first drawing indicates less professional } \\
\text { worker and linear problem solving; second } \\
\text { drawing indicates use of computers, } \\
\text { calculations, and a continuous problem- } \\
\text { solving process }\end{array}$ & + & + & + & \# \\
\hline $\mathrm{C}$ & $\begin{array}{l}\text { Second drawing indicates teamwork and } \\
\text { more input from non-engineers; the written } \\
\text { explanation indicates engineers engage } \\
\text { social issues, use knowledge beyond math } \\
\text { and science. }\end{array}$ & + & + & + & $*$ \\
\hline $\mathrm{D}$ & $\begin{array}{l}\text { The first drawing and explanation focus on } \\
\text { a civil engineer building a structure; the } \\
\text { second drawing indicates the use of } \\
\text { computers and public speaking, the } \\
\text { explanation focused on the need for faculty } \\
\text { to persuade people to understand a problem } \\
\text { and to conduct research to understand } \\
\text { needs. }\end{array}$ & + & + & + & + \\
\hline $\mathrm{E}$ & $\begin{array}{l}\text { Both drawings were identical and suggested } \\
\text { an engineer works in isolation; problem } \\
\text { solving is linear. Explanation in the second } \\
\text { drawing outlines uses of research. }\end{array}$ & & & & + \\
\hline $\mathrm{F}$ & $\begin{array}{l}\text { Both drawings are very similar, but the } \\
\text { explanations are different. At the end of the } \\
\text { semester, the student indicates engineers are } \\
\text { well-rounded and business-like, not nerdy. }\end{array}$ & $*$ & & + & + \\
\hline $\mathrm{G}$ & $\begin{array}{l}\text { Both drawings are the same with different } \\
\text { explanations. At the end of the semester, } \\
\text { the student indicates engineers develop } \\
\text { multiple solutions and use knowledge } \\
\text { beyond math and science }\end{array}$ & & & & $*$ \\
\hline $\mathrm{H}$ & $\begin{array}{l}\text { Both drawings had minimal meaning, but } \\
\text { the written explanations were more } \\
\text { extensive. At the first, the explanation } \\
\text { indicates engineer helps people. The second } \\
\text { explanation includes statements about } \\
\text { consumers, innovation and contributing to } \\
\text { benefit society. }\end{array}$ & & & + & \\
\hline
\end{tabular}

Notes: The symbol + indicates that the end-of-the-semester drawing had one difference compared to the beginning-of-the-semester drawing. The symbol * indicates that the end-of-the-semester drawing had two or three differences compared to the beginning-of-thesemester drawing. The symbol \# indicates that the end-of-the-semester drawing was very different compared to the beginning-of-thesemester drawing. 
Table 2. Summary of the Comparison of the Pre and Post Draw-an-Engineer-Test from Students in the "Traditional Engineering" control group

\begin{tabular}{|c|c|c|c|c|c|}
\hline & 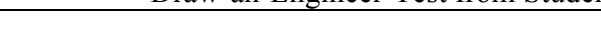 & \multicolumn{4}{|c|}{ Themes } \\
\hline Student & $\begin{array}{c}\text { Short description of the changes noted in } \\
\text { the drawing }\end{array}$ & Image & $\begin{array}{c}\text { Engineering } \\
\text { Process }\end{array}$ & $\begin{array}{l}\text { Humanities } \\
\text { and Social } \\
\text { Science } \\
\text { Aspects }\end{array}$ & $\begin{array}{c}\text { Types of } \\
\text { Knowledge }\end{array}$ \\
\hline $\mathrm{P}$ & $\begin{array}{l}\text { Both drawings are the same depiction of a } \\
\text { suspension bridge. The first written } \\
\text { explanation focuses on construction whereas } \\
\text { the explanation of the second one focuses on } \\
\text { handling loads. }\end{array}$ & & & & + \\
\hline Q & $\begin{array}{l}\text { Both drawings are of the Eiffel Tower, and } \\
\text { both written explanations mention knowledge } \\
\text { of materials is needed. The second } \\
\text { explanation also indicates the need to know } \\
\text { safety. }\end{array}$ & & & & + \\
\hline $\mathrm{R}$ & $\begin{array}{l}\text { Both drawings are of simple stick figures and } \\
\text { outline design as a linear process of analysis } \\
\text { and implementation. }\end{array}$ & & & & \\
\hline $\mathrm{S}$ & $\begin{array}{l}\text { Both drawings are of a person putting } \\
\text { together a puzzle. Both explanations indicate } \\
\text { an engineer is a problem solver. }\end{array}$ & & & & \\
\hline $\mathrm{T}$ & $\begin{array}{l}\text { Both drawings depict the construction of a } \\
\text { building and the use of blueprints. The } \\
\text { explanation in the second drawing is focused } \\
\text { on calculations and testing and the need to } \\
\text { follow code. }\end{array}$ & & & & $*$ \\
\hline $\mathrm{U}$ & $\begin{array}{l}\text { Both drawings depict a structure, and the } \\
\text { written explanations indicate that the engineer } \\
\text { is a skilled individual who uses calculations. } \\
\text { The second explanation mentions that the } \\
\text { engineer must develop the best solution for } \\
\text { the situation. }\end{array}$ & & + & & \\
\hline V & $\begin{array}{l}\text { The first drawing shows computers and a } \\
\text { bridge; the second drawing shows computers } \\
\text { and a skyscraper with wind loads. Both } \\
\text { explanations indicate the need to know } \\
\text { physics, chemistry, and math. }\end{array}$ & & & & \\
\hline W & $\begin{array}{l}\text { Both drawings depict an engineer as a } \\
\text { construction worker. The written explanations } \\
\text { of both drawings suggest the engineer is a } \\
\text { manager who tells others how to construct a } \\
\text { building. }\end{array}$ & & & & \\
\hline
\end{tabular}

Notes: The symbol + indicates that the end-of-the-semester drawing had one difference compared to the beginning-of-the-semester drawing. The symbol * indicates that the end-of-the-semester drawing had two or three differences compared to the beginning-of-thesemester drawing. 
Table 3. Summary of the Comparison of the Pre and Post Draw-an-Engineer-Test from Students in the "Non-Engineering" control group

\begin{tabular}{|c|c|c|c|c|c|}
\hline & & & & & \\
\hline Student & $\begin{array}{c}\text { Short description of the changes noted in } \\
\text { the drawing }\end{array}$ & Image & $\begin{array}{l}\text { Engineering } \\
\text { Process }\end{array}$ & $\begin{array}{l}\text { Humanities } \\
\text { and Social } \\
\text { Science } \\
\text { Aspects } \\
\end{array}$ & $\begin{array}{l}\text { Types of } \\
\text { Knowledge }\end{array}$ \\
\hline I & $\begin{array}{l}\text { Both drawings were very similar to similar } \\
\text { explanations. The student indicates the } \\
\text { information provided is based on a friend } \\
\text { who is a mechanical engineer }\end{array}$ & & & & \\
\hline $\mathrm{J}$ & $\begin{array}{l}\text { The first drawing was very specific about } \\
\text { what an engineer may look like and wrote } \\
\text { the engineer is older and very smart. The } \\
\text { second drawing is simple with more } \\
\text { explanation indicating engineers must have } \\
\text { a strong social connection and could be } \\
\text { anyone. Also, the second explanation } \\
\text { mentions sustainability. }\end{array}$ & + & & $*$ & \\
\hline $\mathrm{K}$ & $\begin{array}{l}\text { Both drawings are simple stick figures; both } \\
\text { explanations are similar that engineers help } \\
\text { people. The explanation in the second } \\
\text { drawing mentions engineers help people in } \\
\text { developing countries have clean water }\end{array}$ & & & + & \\
\hline $\mathrm{L}$ & $\begin{array}{l}\text { First drawing and written explanation } \\
\text { indicates a person building a sewage } \\
\text { system. The second drawing depicts } \\
\text { someone lecturing to others and explains } \\
\text { engineers educate people how to manage } \\
\text { facilities. The written explanations indicate } \\
\text { the perception of moving from providing a } \\
\text { "system or solution" to teaching how to use } \\
\text { and maintain the system or solution. }\end{array}$ & + & & + & \\
\hline M & $\begin{array}{l}\text { Both drawing indicate an engineer working } \\
\text { at a desk, the second drawing includes the } \\
\text { engineer presenting to a group. Negligible } \\
\text { explanations are provided in both drawings. }\end{array}$ & & & & \\
\hline $\mathrm{N}$ & $\begin{array}{l}\text { Both drawings and written explanations } \\
\text { depict a roller-coaster and a bridge. Both } \\
\text { explanations indicate the same knowledge } \\
\text { set of physics and math are needed. }\end{array}$ & & & & \\
\hline $\mathrm{O}$ & $\begin{array}{l}\text { Both drawings are of the same types of } \\
\text { images of a light bulb and an airplane. Both } \\
\text { explanations indicate engineers create } \\
\text { technology and are intellectual individuals. }\end{array}$ & & & & \\
\hline
\end{tabular}

Notes: The symbol + indicates that the end-of-the-semester drawing had one difference compared to the beginning-of-the-semester drawing. The symbol * indicates that the end-of-the-semester drawing had two or three differences compared to the beginning-of-thesemester drawing. 


\section{Student Interviews}

Three students from the "Water Module" group volunteered to be interviewed at both the beginning and the end of the semester. Four students in "Traditional Engineering" group were interviewed once at the end of the semester. These students were asked the same questions regarding perceptions of engineering and its role in society, and were asked to evaluate the teaching methods in their course. Following the university's human subject guidelines, only student who volunteered to participate in the interview component of this project could be interviewed. No students in the Non-engineering group participated in the interview component of this research.

\section{Perceptions of Engineering Theme}

An engineering major who belonged to the "Water Module" Group indicated that she/he changed her/his opinion regarding engineering knowledge. In the first interview, the student emphasized that the ideal engineer would need to be good at math and science, but $\mathrm{s} /$ he noted that engineers need to collaborate with other professionals and be "sociable." However, in the follow-up interview, this student expressed a broader view of engineering indicating that "...it's not just if you're good at math and science, then you'll be a good engineer." This student's response indicated a transition away from the traditional view of engineering to one where the engineer needs a broader set of knowledge and skills. A non-engineering major in this group initially indicated that $\mathrm{s} / \mathrm{he}$ perceived that people with liberal arts education were more concerned with interacting with people than engineers. In the second interview, this student's perception changed to one where $\mathrm{s} / \mathrm{he}$ emphasized that engineers had a business side and needed to have considerable people skills. At the end of the course, the student indicated an interest in engineering as a career choice. Another non-engineering major belonging to the "Water Module" group originally expressed a strong people-oriented view of engineering and this perspective did not change over the course of the semester. While the student began the course with the concept that engineered products can help people, s/he illustrated a deeper understanding of engineering interaction with society during the end-of-thesemester interview.

The four students in the "Traditional Engineering" group interviewed indicated engineers need to anticipate unintended consequences. However, none of these students suggested that these consequences could be of a social nature, or that engineers needed to consider social issues. One student noted the importance of communication as a skill to help "selling ideas" while another student emphasized engineering as an isolated profession where the engineer worked alone. In the end-of-the-semester interviews, student responses indicate that they perceived engineering as primarily involving planning, designing, and fabrication. This course focused on the technical aspects of constructing the World Trade Centers with little if any content of humanities and social science topics, so these findings are not surprising.

\section{Humanities and Social Science Connections to Engineering Theme}

In both the beginning-of-the-semester and the end-of-the-semester interviews of the "Water Module" group, students expressed ideas that did not differ much; however, students were more specific in their explanations at the end of the semester. For example, one student explained that political aspects were important to engineering work because engineers need government approval or involvement. At the end of the course, the same student provided evidence that $\mathrm{s} /$ he understood getting government funding could have a social impact by stating "Like if they try to get [government] funding for [the solution] and like what kind of taxes would that impose on the people in order to make that work." Two other students in this group made statements that an engineer needed to gain collaboration among people from different fields and needed to understand how people felt about the engineered solution. Overall, the "Water Module" Group demonstrated an understanding of how engineering impacts society and that researching the context of a problem and interviewing people were responsibilities of an engineer.

Most students in the "Traditional Engineering" group identified history as a humanities and social science subject and were able to assert the importance of referring to past events in order to prevent future mistakes in engineering. These students understood the value in using history to analyze engineering problems in the past or when preparing for events that may reoccur. They did not include any historical analysis of people, location, or culture for a stronger social connection. Also, one student indicated the need to understand safety issues, stating 
“...you know, if you're designing something that's potentially going to hurt somebody, then it's not good...You want to design it where it...it's efficient, and you know, it has a low impact." The students could be making these connections due to assignments where they were required to learn the history and the background of the terrorist who flew planes into the World Trade Center buildings.

\section{Evaluation of Teaching Styles}

Students in the "Water Module" group concurred that the course stimulated independent and critical thinking. Students admitted that they were unaccustomed to this teaching style, which caused some discomfort initially. However, in the end, they seemed to convey a positive attitude regarding the method. One student stated " $I$ like it personally, of course, you know because it makes you think, basically. ...When they ask for your input, you have to stay focused and uh, yeah, learn." Another student said, "I like dealing with like actual situations as opposed to just like complete hypotheticals when no examples are given." One of the purposes of the integrative learning module was to provide a real-world example of an engineering problem so that students could examine the social and engineering aspects of it. Students seemed to appreciate the active learning approach even though they found it more challenging than the passive methods they had experienced previously.

The students in the "Traditional Engineering" group expressed a positive attitude toward their learning experience, as well. They enjoyed the lab demonstrations that enhanced visual learning. One student indicated that while the class and demonstrations were enjoyable, the student did not retain much information from the teachercentered and passive learning environment that existed in the majority of the class meetings. This student stated "Um, the teaching style itself was very interesting because I was very entertained. . . However, I wouldn't say that I remembered a lot" The instructor for this course section is very dynamic in his method of delivering lecture material and entertains students by using jokes to point out crucial elements and when he ask questions. However, this instructor uses traditional "chalkboard" lectures to deliver content, which explains students feeling "entertained" but also considering that they could not remember much.

\section{CONCLUSION}

Overall, the "Water Module" group indicated the most change in perceptions about engineering. The integrative learning module appears to be effective challenging traditional stereotypes about engineering, and helping students realize the interdisciplinary nature of engineering work, and its impact on society. Most importantly, students enjoyed the integrative learning module and found it challenging and novel compared to other teaching approaches.

This study had some limitations. Students self-selected to each of the courses and were all from diverse backgrounds and majors, which likely influenced their approach to engineering. For instance, students majoring in the humanities may intuitively adopt a humanistic approach to situations whereas those majoring in engineering or the sciences may not. Also, students choosing an engineering course may have different attitudes toward new information about engineering. Consequently, differences found in the study cannot be solely linked to the content and pedagogy of the courses. Furthermore, the professors and their style may have impacted the results. Also, the gender, practices, research, and departments of the professors could have influenced students' perceptions of engineers in the second assessment.

Despite these limitations, there is sufficient evidence to indicate that the integrative learning module is useful in integrating the humanities, social sciences, and engineering, and helping further develop students' perceptions of engineers. With subjects often taught in isolation, this study suggests that students often fail to understand the true applications of math and science concepts, which may limit their ability to choose engineering as a career. Further, students using contextualized, integrative, and interdisciplinary approaches may be able to develop better higher order thinking skills to solve complex engineering problems While one course alone may not be able to solve limitations in the entire curriculum, it facilitates a transition toward integrative, interdisciplinary, and wholistic thinking, making it easier for students to accept other similar courses, and with time develop the skills to integrate ideas, processes, and knowledge between different courses, and continue developing these skills throughout their careers. 
This study used an integrative learning module in a post-secondary context; future studies are needed to show the effectiveness of integrative learning modules in K-12 STEM learning contexts. Further studies should also add other types of data, including quantitative and qualitative learning assessments (tests, projects, papers) focused evaluating higher order learning skills, impact on student learning engagement, and longitudinal data such as student retention and career placement. These studies are needed not only to improve learning in engineering fields but also increase student enrollment and retention in engineering majors in higher education.

\section{AUTHOR INFORMATION}

Dr. Singer is a PhD candidate in Social Foundations of Education at the University of Georgia and has had over 6 years of experience teaching high school English. Dr. Singer's research interests include global obesity and health education with a focus on studies of obesity's impact on educational achievement and experience. Dr. Singer is currently working in Shanghai, China as an academic administrator in international education.

Dr. Foutz has taught engineering design courses since 1990 and has received federal funding to integrate humanities and social science topics into his course materials. Since 2007, Dr. Foutz has been an invited participant of the Symposium for Engineering and Liberal Education. He has teamed with faculty from the UGA School of Music and faculty from the UGA School of Art to teach design courses where the engineering students had to infuse techniques from music and/or art into their technical solutions.

Dr. Navarro's main research focus is the enhancement of the Higher Education curriculum to achieve a more global, integrated, and socially conscious curriculum, with particular interest on STEM disciplines. From an outreach perspective, Dr. Navarro has extensive experience as a researcher, instructor, and facilitator of professional development programs for university teaching faculty (STEM disciplines), and has worked in the US, Latin America, Africa, the Middle East, and Western Asia. Her background in both agricultural engineering (B.S.) and education (Ph.D.), positions her well to address professional development of engineering faculty.

Dr. Thompson is a Professor in the Department of Biological and Agricultural Engineering and Coordinator of Undergraduate Engineering Programs at The University of Georgia. Dr. Thompson received a Ph.D. in 1981 from the University of Kentucky in Agricultural Engineering. Dr. Thompson teaches undergraduate courses in engineering mechanics, engineering design and structural design. His research focuses on structural design, granular mechanics and engineering education.

\section{REFERENCES}

Beggs, J. M., Bantham, J. H., \& Taylor, S. (2008). Distinguishing the factors influencing college students' choice of major. College Student Journal, 42(2), 381-394.

Besterfield-Sacre, M., Atman, C. J., \& Shuman, L. J. (1998). Engineering student attitudes assessment. Journal of Engineering Education, 87(2), 133-141. doi: 10.1002/j.2168-9830.1998.tb00333.x

Bowen, E., Prior, J., Lloyd, S., Thomas, S., \& Newman-Ford, L. (2007). Engineering more engineers—bridging the mathematics and careers advice gap. Engineering education, 2(1), 23-32. doi: 10.11120/ened.2007.02010023

Chambers, D. W. (1983). Stereotypic images of the scientist: The Draw-a-Scientist Test. Science education, 67(2), 255-265. doi: $10.1002 /$ sce.3730670213

Clark, R., \& Andrews, J. (2011). Balancing expectations in engineering education: Enhancing student experiences through empirical research - a comparative analysis. In SEFI, $1^{\text {st }}$ World Engineering Education Flash Week, Lisbon, Portugal, pp. 465-469. Available from: http://www.sefi.be/wpcontent/papers2011/T9/239.pdf.

Dabbagh, N., \& Menascé, D. A. (2006). Student perceptions of engineering entrepreneurship: An exploratory study. Journal of Engineering Education, 95(2), 153-164. doi: 10.1002/j.2168-9830.2006.tb00886.x

English, L. D., Hudson, P. B., \& Dawes, L. A. (2011, January). Middle school students' perceptions of engineering. In STEM in Education Conference: Science, Technology, Engineering and Mathematics in Education Conference. Queensland University of Technology. 
Ettouney, O. M. (1994). A new model for integrating engineering into the liberal education of non-engineering undergraduate students. Journal of Engineering Education, 83(4), 349-356. doi: 10.1002/j.21689830.1994.tb00130.x

Fantz, T. D., Siller, T. J., \& DeMiranda, M. A. (2011). Pre-collegiate factors influencing the self-efficacy of engineering students. Journal of Engineering Education, 100(3), 604-623.

Foutz, T., Navarro, M., Patrick Singer, K., \& Thompson, S. (2015). Development of a pedagogical model to help engineering faculty design interdisciplinary curricula. Manuscript submitted for publication.

Foutz, T., Navarro, M., B Hill, R., A Thompson, S., Miller, K., \& Riddleberger, D. (2011). Using the discipline of agricultural engineering to integrate math and science. Journal of STEM Education, 12(1), 24-32.

Froyd, J. E., \& Ohland, M. W. (2005). Integrated engineering curricula. Journal of Engineering Education, 94(1), 147-164. doi: 10.1002/j.2168-9830.2011.tb00028.x

Hartman, H., \& Hartman, M. (2006). Leaving engineering: Lessons from Rowan University's college of engineering. Journal of Engineering Education, 95(1), 49-61. doi: 10.1002/j.2168-9830.2006.tb00877.x

Jones, B. D., Paretti, M. C., Hein, S. F., \& Knott, T. W. (2010). An analysis of motivation constructs with first-year engineering students: Relationships among expectancies, values, achievement, and career plans. Journal of Engineering Education, 99(4), 319-336. doi: 10.1002/j.2168-9830.2010.tb01066.x

Knight, M., \& Cunningham, C. M. (2004, June). Draw an engineer test (DAET): Development of a tool to investigate students' ideas about engineers and engineering. In Proceedings of the ASEE Annual Conference and Exposition, Salt Lake City, Utah.

Lichtenstein, G., McCormick, A. C., Sheppard, S. D., \& Puma, J. (2010). Comparing the undergraduate experience of engineers to all other majors: Significant differences are programmatic. Journal of Engineering Education, 99(4), 305-317. doi: 10.1002/j.2168-9830.2010.tb01065.x

Lincoln, Y. S., \& Guba, E. G. (1985). Naturalistic inquiry. Newbury Park, CA: Sage.

Marra, R. M., Rodgers, K. A., Shen, D., \& Bogue, B. (2012). Leaving engineering: A multi-year single institution study. Journal of Engineering Education, 101(1), 6-27. doi: 10.1002/j.2168-9830.2012.tb00039.x

Miele, E. (2014). Using the Draw-a-Scientist Test for Inquiry and Evaluation. Journal of College Science Teaching, 43(4), 36-40.

Milford, T., \& Tippett, C. (2013). Preservice teachers' images of scientists: Do prior science experiences make a difference? Journal of Science Teacher Education, 24(4), 745-762. doi:10.1007/s10972-012-9304-1

Ohland, M. W., Sheppard, S. D., Lichtenstein, G., Eris, O., Chachra, D., \& Layton, R. A. (2008). Persistence, engagement, and migration in engineering programs. Journal of Engineering Education, 97(3), $259-278$. doi: 10.1002/j.2168-9830.2008.tb00978.x

Oware, E., Capobianco, B., \& Diefes-Dux, H. A. (2007, October). Young children's perceptions of engineers before and after a summer engineering outreach course. In Proceedings of the $37^{\text {th }}$ ASEE/IEEE Frontiers In Education Conference, Milwaukee, WI. (pp. S2B-3 to S2B-8).

Singer, K. P., Foutz, T. L., Navarro, M., Thompson, S. (2011). Integrating the humanities and engineering: The implications of an interdisciplinary-based learning module. In Proceedings of the ASEE Southeastern Section Conference. Charleston, SC. (pp. 1-10).

Walden, S. E., \& Foor, C. (2008). "What's to keep you from dropping out?" Student immigration into and within engineering. Journal of Engineering Education, 97(2), 191-205. doi: 10.1002/j.2168-9830.2008.tb00967.x

Walmsley, A., Wilson, T., \& Morgan, C. (2010). Influences on a college student's major: A developmental perspective. Journal for the Liberal Arts and Sciences, 14(2), 25-46.

Wingert, J. R., Wasileski, S. A., Peterson, K., Mathews, L. G., Lanou, A. J., \& Clarke, D. (2011). Enhancing integrative experiences: Evidence of student perceptions of learning gains from cross-course interactions. Journal of the Scholarship of Teaching and Learning, 11(3), 34-57. 
NOTES 